\title{
PERENCANAAN STRUKTUR DERMAGA EMERGENCY JETTY TRUCKING KAPASITAS 10.000 DWT PELABUHAN RATU SUKABUMI JAWA BARAT
}

\author{
Nico Aprianto', Dasa Aprisandi ${ }^{2}$, Widi Nugroho ${ }^{3}$ \\ ${ }^{1,2,3}$ Program Studi Teknik Sipil Universitas Banten Jaya, Jl. Raya Ciwaru II No. 73 Kota Serang, Banten \\ Email: nicoaprian48@gmail.com \\ Email: tellyrosdiyani004@gmail.com
}

\begin{abstract}
ABSTRAK
Dermaga emergency jetty ini merupakan dermaga bertipe jetty dengan kapasitas $10.000 \mathrm{dwt}$ yang terletak di Jalan Raya Cipatuguran Desa Jayanti, Citarik, Kecamatan Pelabuhan Ratu, Sukabumi Regency, Jawa Barat 43364. Dermaga ini dimiliki oleh PT Indonesian Power UJP Jabar 2 yang digunakan untuk menunjang proses kegiatan unloading batubara dari kapal tongkang ke truk bermuatan yang kemudian akan di distribusikan ke PLTU UJP Jabar 2 untuk diproses menjadi listrik. Perencanan ini menggunakan metode penelitian kuantitatif yaitu data primer dan sekunder yang terdiri dari data-data perencanaan standar dermaga, data pembebanan, data spesifikasi material dan data oceanografi yang diolah menggunakan software SAP2000, Autocad dan lain-lain, kemudian penelitian dilakukan selama \pm 6 bulan. Perencanaan dermaga ini berfokus pada struktur atas (Plat lantai,balok dan fender) dan struktur bawah (poer dan pondasi tiang pancang) dengan dimensi dermaga $120 \times 31 \mathrm{~m}$ serta fasilitas seperti fender dan bollard. Dari hasil perencanaan struktur didapat mutu beton rata-rata menggunakan $\mathrm{K} .430 / \mathrm{f}^{\circ} \mathrm{c}=$ $35 \mathrm{MPa}$ dan mutu baja rata-rata $\mathrm{f}^{\mathrm{fe}} \mathrm{y}=400 \mathrm{MPa}$. Perencanaan struktur atas rinciannya seperti pelat lantai direncanakan tebal $400 \mathrm{~mm}$, untuk balok mempunyai beberapa dimensi dengan rincian balok melintang $700 \times 800 \mathrm{~mm}$, balok memanjang 700x800mm dan balok area mekanikal 1200x $800 \mathrm{~mm}$ serta untuk fender memiliki jarak antar fender $10 \mathrm{~m}$. sedangkan struktur bawah rinciannya seperti poer/pilecap 1500x1500x800mm untuk area dengan beban standar, pilecap slab fix crane 8000x8700x1200mm, pilecap hopper 25300x14000x1200mm. sedangkan untuk tiang pancang menggunakan Steel Pipe Pile dengan diameter $\varnothing 914 \mathrm{~mm}$ dan tebal $16 \mathrm{~mm}$ dan $22 \mathrm{~mm}$ serta panjang $31 \mathrm{~m}$ dangan kedalaman $20,45 \mathrm{~m}$.
\end{abstract}

Kata Kunci: Pelabuhan Ratu, Dermaga, Struktur Atas dan bawah, Jetty.

\begin{abstract}
This emergency jetty pier is a jetty type dock with a capacity of 10,000 dwt located on Jalan Raya Cipatuguran Jayanti Village, Citarik, Pelabuhan Ratu District, Sukabumi Regency, West Java 43364. This wharf is owned by PT Indonesian Power UJP Jabar 2 which is used to support the process of activities unloading coal from a barge to a loaded truck which will then be distributed to the West Java UJP 2 power plant to be processed into electricity. This planning uses quantitative research methods, namely primary and secondary data consisting of pier standard planning data, loading data, material specification data and oceanographic data which are processed using SAP2000 software, Autocad and others, then the study is conducted for \pm 6 months. This pier planning focuses on the upper structure (floor plates, beams and fenders) and the lower structure (piles and pile foundations) with $120 \times 31 \mathrm{~m}$ pier dimensions and facilities such as fenders and bollards. From the results of structural planning the average concrete quality is obtained using $K .430 / f c=35 \mathrm{MPa}$ and the average steel quality fy= 400 $M P a$. Structural planning for details such as floor plates are planned to be $400 \mathrm{~mm}$ thick, for beams having several dimensions with details of transverse beams $700 x 800 \mathrm{~mm}$, longitudinal beams $700 \times 800 \mathrm{~mm}$ and beam mechanical areas of $1200 \times 800 \mathrm{~mm}$ and for fenders having a $10 \mathrm{~m}$ distance between fenders. while the structure under the details such as poer / pilecap $1500 \times 1500 \times 800 \mathrm{~mm}$ for areas with standard loads, pilecap slab fix crane $8000 \times 8700 \times 1200 \mathrm{~mm}$, pilecap hopper 25300x14000x1200mm. whereas for piles using Steel Pipe Pile with a diameter of $\emptyset 914 \mathrm{~mm}$ and thickness of $16 \mathrm{~mm}$ and $22 \mathrm{~mm}$ and a length of $31 \mathrm{~m}$ with a depth of $20.45 \mathrm{~m}$.
\end{abstract}

Keywords: Pelabuhan Ratu, Dock, Upper and Lower Structure, Jetty. 


\section{PENDAHULUAN}

Pelabuhan adalah tempat atau fasilitas di ujung daratan, sungai, danau atau di pesisir pantai yang berfungsi untuk tempat berlabuh atau bersandar dan menerima kapal yang datang ataupun keluar dan juga transportasi air lainnya, serta melakukan proses menaikkan dan menurunkan penumpang, bongkar muat barang atau kargo maupun hewan dan juga tempat dilakukannya kegiatan perekonomian. PT. Indonesia Power selaku owner telah melakukan Pengembangan Bisnis Jasa Operasi Pemeliharaan di seluruh Indonesia baik melalui pengelolaan sendiri, maupun melalui Anak perusahaan. Salah satu UJP yang sekarang memerlukan tambahan fasilitas penunjang yaitu UJP Jawa barat 2 di sukabumi. Fasilitas yang diperlukan oleh PT Indonesian Power guna menunjang proses kegiatan unloading batubara di pelabuhan selain dermaga existing maka diperlukan dermaga tambahan yaitu dermaga emergency system trucking untuk bongkar muat batubara dari kapal tongkang ke truk bermuatan yang kemudian akan di distribusikan ke PLTU UJP Jabar 2 untuk diproses menjadi listrik. Tipe dermaganya itu sendiri yaitu jetty sedangkan perencanaan struktur yang diambil terdiri dari struktur atas (balok,plat lantai, poer) dan struktur bawah (tiang pancang). Sementara lokasi rencana dermaga yang akan dibangun berada persis dibelakang PT Indonesia Power yang berada disekitar bibir pantai atau di jalur pelayaran ataupun didekat break water dengan koordinat GPS 701'31.5" Lintang Selatan dan 106 $32 ' 31.8^{\prime \prime}$ Bujur timur. Sementara koordinat latitude -7.025421 dan koordinat longitude 106.542164.

Tujuan dan Maksud dari adanya penyusunan Tugas Akhir perencanaan dermaga jetty ini yaitu :

1. Merencanakan desain struktur atas (Plat lantai,balok dan fender) dan struktur bawah (poer dan pondasi tiang pancang) pada dermaga emergency jetty trucking yang meliputi: panjang, lebar, dan elevasi dermaga.

2. menganalisis gaya pada struktur dermaga jetty dalam merespon beban-beban yang bekerja.

3. Untuk menentukan beban-beban yang bekerja pada struktur dermaga jetty tersebut.

\section{METODOLOGI PENELITIAN}

\subsection{Metode Penelitian}

Metode penelitian yaitu suatu cara ilmiah untuk memperoleh data dengan tujuan dan fungsi tertentu. Pada penelitian ini metode yang digunakan yaitu metode kuantitatif. Subjek penelitian dalam hal ini adalah sumber informasi yang didapat yaitu dari PT Indonesia Power dan buku-buku panduan perencanaan, sedangkan objek penelitiannya adalah Struktur Dermaga Emergency Jetty Trucking Kapasitas 10.000 dwt Pelabuhan Ratu Sukabumi Jawa Barat.

\subsection{Tempat dan Waktu Penelitian}

Berlokasi Jalan Raya Cipatuguran Desa Jayanti, Citarik, Kec. Pelabuhan Ratu, Sukabumi Regency, Jawa Barat 43364. Sedangkan dermaganya berada disekitar bibir pantai pelabuhan ratu atau di jalur pelayaran ataupun didekat break water dengan koordinat GPS $7^{\circ} 01^{\prime} 31.5^{\prime \prime}$ Lintang Selatan dan 106 32'31.8" Bujur timur. Sementara koordinat latitude -7.025421 dan koordinat longitude 106.542164. Sedangkan Penelitian ini direncanakan pada semester delapan kurang lebih dalam kurun waktu enam bulan yaitu mulai dari bulan maret 2020 sampai dengan agustus 2020.

\subsection{Variabel dan Instrumen Penelitian}

Pada pengumpulan data ini dilakukan melalui beberapa ketentuan, syarat-syarat dan pedoman yang tersusun secara sistematis. Penelitian ini bertipe penelitian kuantitatif, sehingga variabelnya yang muncul dalam penelitian mengenai Perencanaan Struktur Dermaga Emergency Jetty Trucking Kapasitas 10.000 dwt Pelabuhan Ratu Sukabumi Jawa Barat, antara lain :

1. Data Primer

Data primer yang diperlukan yaitu:

1) Data lokasi proyek

2) Permasalahan yang dihadapi di lokasi proyek

2. Data Sekunder

Data sekunder yang diperlukan yaitu :

1) Data-data perencanaan standar dermaga

2) Data pembebanan

3) Data spesifikasi material 
4) Data oceanografi seperti arus, gelombang, angin, temperature dan gempa.

5) Peta tata guna lahan

3. Software program

Software yang digunakan untuk mempermudah peroses perencanaan yaitu SAP (Structural Analysis Program) 2000, AutoCAD dan software tambahan lainnya.

\subsection{Rencana Analisis Data}

Analisa data merupakan prosedur utama dalam melakukan penelitian yang berfungsi untuk menarik suatu kesimpulan. Pada tahapan ini prosedur pengolahan data diperoleh dari data primer maupun data sekunder yang selanjutnya dilakukan analisis data perencanaan. Adapun tahapan proses analisis datanya antara lain:

1. Data Oceanografi

2. Data Tanah

3. Data Jumlah Kapal dan Jenis Kapal

4. Data Jumlah Bongkar Muat Barang

5. Data Perencanaan Dermaga

6. Data Gambar Konstruksi

7. Syarat-syarat Teknis dan Administrasi

\section{ANALISA DATA DAN PEMBAHASAN}

\subsection{Analisis Struktur}

1. Elevasi Jetty

Desain kedalaman seabed di muka dermaga adalah pada MSL. Dengan kondisi kedalam desain actual adalah bervariasi. Elevasi deck dermaga adalah $+3.8 \mathrm{~m}$ (ref 0.00 MSL).

2. Penentuan Fixity Point Pondasi Tiang Pancang

Kebutuhan panjang pile untuk analisa struktur adalah

$\mathrm{L}=$ Pile Cut Off + Kedalaman seabed dari muka air $0+$ panjang fixity point

$$
=2,5+7,5+14,35=24,35 \approx 25 \mathrm{~m}
$$

3. Penentuan Fixity Point Pondasi Tiang Pancang

1. Elemen Struktur Bawah

$$
\begin{aligned}
& \text { Pondasi tiang pancang : } \\
& \text { SPP } \varnothing 914 \mathrm{~mm}(\mathrm{t}=16 \mathrm{~mm}) \\
& \mathrm{OD}=914 \mathrm{~mm} \\
& \text { ID }=898 \quad \mathrm{~mm} \\
& \mathrm{t}(\text { tebal })=16 \quad \mathrm{~mm} \\
& \text { fy } \quad=315 \quad \mathrm{MPa} \\
& \text { SPP } \varnothing 914 \mathrm{~mm}(\mathrm{t}=22 \mathrm{~mm}) \\
& \mathrm{OD}=914 \mathrm{~mm} \\
& \text { ID }=892 \mathrm{~mm} \\
& \mathrm{t} \text { (tebal) }=22 \quad \mathrm{~mm} \\
& \text { fy } \quad=315 \quad \mathrm{MPa}
\end{aligned}
$$

2. Elemen Struktur Atas:

\section{Pelat lantai:}

$$
\begin{array}{lll}
\mathrm{t}(\text { tebal }) & =400 \quad \mathrm{~mm} \\
\mathrm{f}^{\prime} \mathrm{c} & =35 \quad \mathrm{MPa} \\
\mathrm{E} & =27.80 \times 10^{3} \quad \mathrm{Mpa}
\end{array}
$$




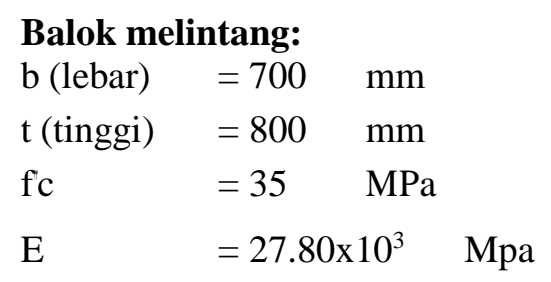

Balok memanjang:

$$
\begin{array}{rll}
\mathrm{b} \text { (lebar) } & =700 \quad \mathrm{~mm} \\
\mathrm{t} \text { (tinggi) } & =800 \mathrm{~mm} \\
\mathrm{fc} & =35 \quad \mathrm{MPa} \\
\quad \mathrm{E} & \multicolumn{2}{c}{=27.80 \times 10^{3} \quad \mathrm{Mpa}}
\end{array}
$$

Balok di titik mesin handling:

$$
\begin{array}{lll}
\mathrm{b}(\text { lebar) } & =1200 & \mathrm{~mm} \\
\mathrm{t} \text { (tinggi) } & =800 & \mathrm{~mm} \\
\mathrm{fc} & =35 & \mathrm{MPa}
\end{array}
$$

$$
\mathrm{E} \quad=27.80 \times 10^{3} \quad \mathrm{Mpa}
$$

\section{Pilecap Crane \& Hopper:}

$$
\begin{array}{lll}
\mathrm{t}(\text { tebal }) & =1200 \mathrm{~mm} \\
\mathrm{fc} & =35 \mathrm{MPa} \\
\mathrm{E} & =27.80 \times 10^{3} \quad \mathrm{Mpa}
\end{array}
$$

\subsection{Desain Pondasi Tiang Pancang}

Panjang tiang pancang bergantung pada nilai daya dukung tiang terhadap tanah. Adapun perhitungan daya dukung tiang tersaji pada lampiran 1. Rekapitulasi hasil daya dukung dilihat pada tabel dibawah ini.

Tabel 1 Rekapitulasi daya dukung ijin tiang pancang

\begin{tabular}{cccccccc}
\hline \multirow{2}{*}{$\begin{array}{c}\text { H } \\
\text { (m) }\end{array}$} & \multirow{2}{*}{ Pile } & Pall,c (T) & Pall,t $(\mathbf{T})$ & Pall,c (T) & Pall,t (T) & Pall,c (T) & Pall,t (T) \\
\cline { 3 - 8 } 20,45 & D914 T16 & 496,61 & 72,54 & 465,27 & 66,34 & 471,56 & 74,02 \\
\hline 20,45 & D914 T22 & 500,73 & 68,42 & 469,39 & 62,22 & 475,68 & 69,9 \\
\hline \multicolumn{6}{c}{ (Sumber: Software SAP2000, 2020) }
\end{tabular}

Daya Dukung Aksial Tekan

$\mathrm{P} \max =312,32$ Ton (compression)

Pall,c $=465,99$ Ton, based on BH-03

$\mathrm{P} \quad=312,32$ ton $($ compression $)<465,99$ ton $\quad \rightarrow \quad$ OK

Panjang tiang pancang SPP 914 mm untuk struktur jetty dijelaskan berikut ini.

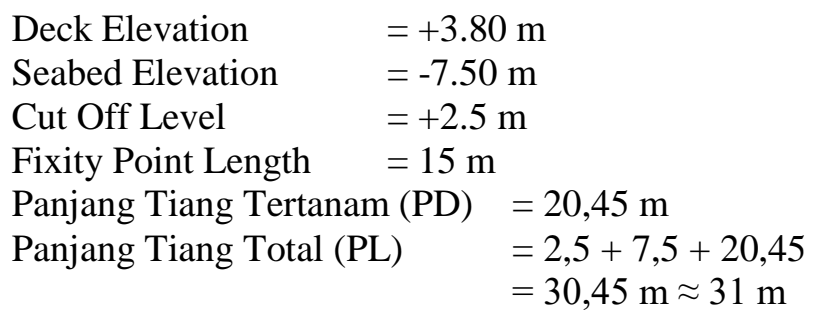


Berdasarkan hasil perhitungan penulangan beton pengisi concrete Steel Pipe Pile menggunakan perhitungan diagram interaksi kolom, bahwa pemasangan 20 tulangan, diameter $25 \mathrm{~mm}$ pada beton pengisi sudah memadai. Penulangan pada beton pengisi bisa dilihat pada gambar dibawah ini:

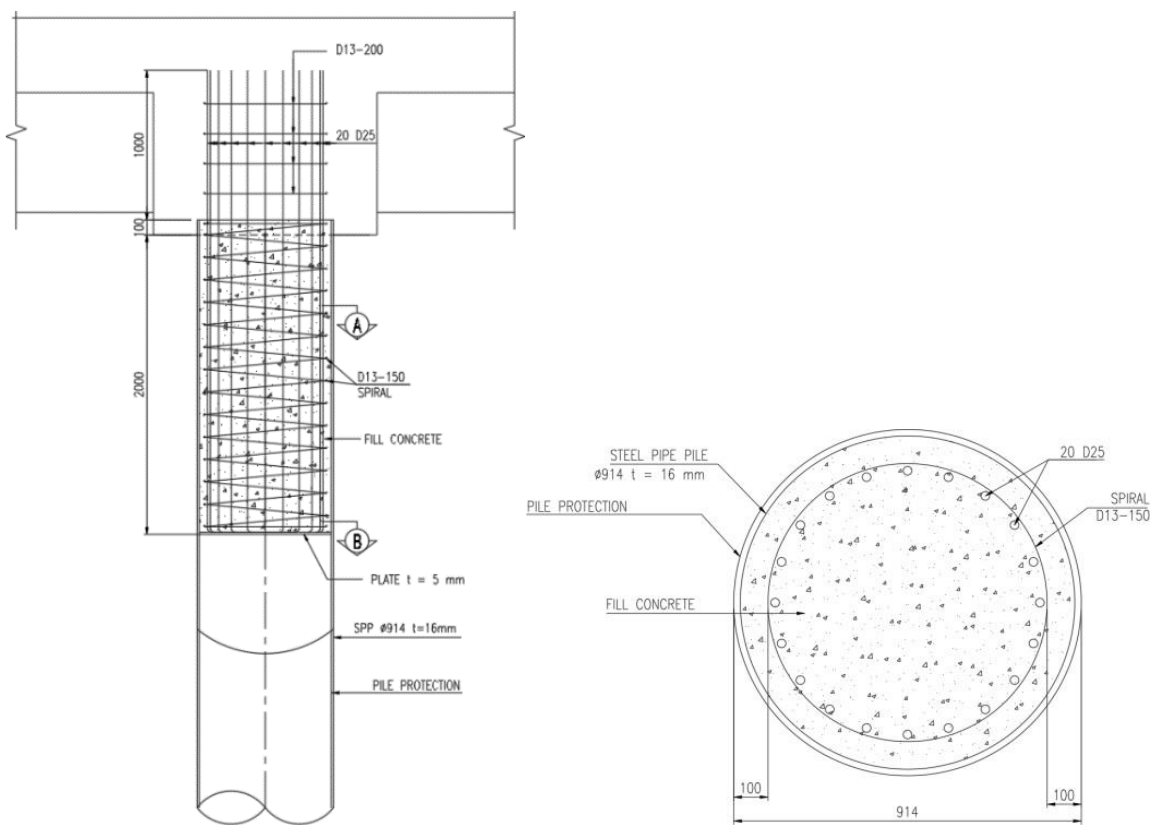

Gambar 4.1 Detail rencana penulangan beton pengisi SPP 914

(Sumber : Software Autocad, 2020)

\subsection{Perencanaan Pelat Lantai}

Gaya dalam yang terjadi pada tiang yang terdapat pada beton pengisi adalah:

Berat mati dari pelat lantai yang merupakan berat sendiri, dengan tebal pelat adalah $400 \mathrm{~mm}$

Beban hidup merata sebesar 3,5 ton $/ \mathrm{m}^{2}$

Beban truck 30 ton capacity.

Pada Stage 1, elemen precast beam berperilaku sebagai balok dengan dua tumpuan sederhana (simply supported beam).

Stage 1

\begin{tabular}{|c|c|c|}
\hline Qsw & $=(0.15 \times 1) \mathrm{m}^{2} \times 2.4 \mathrm{ton} / \mathrm{m}^{3}$ & $=0.36 \mathrm{ton} / \mathrm{m}$ \\
\hline \multirow[t]{2}{*}{ Qwc } & $=(0.15 \times 1) \mathrm{m}^{2} \times 2.4 \mathrm{ton} / \mathrm{m}^{3}$ & $=0.36$ ton $/ \mathrm{m}+$ \\
\hline & Qdl & $=0.72 \mathrm{ton} / \mathrm{m}$ \\
\hline Qll & $=250 \mathrm{~kg} / \mathrm{m}^{2} \times 1 \mathrm{~m}$ & $=0.25 \mathrm{ton} / \mathrm{m}$ \\
\hline
\end{tabular}

Member Force Stage 1 :

\begin{tabular}{|c|c|c|c|c|c|}
\hline $\mathrm{M}_{\mathrm{DL}}$ & $=(1 / 8) \cdot \mathrm{q}_{\mathrm{DL}} \cdot \mathrm{L}^{2}$ & $=$ & 1,968 & ton.m & \\
\hline $\mathrm{M}_{\mathrm{LL}}$ & $=(1 / 8) \cdot \mathrm{q}_{\mathrm{LL}} \cdot \mathrm{L}^{2}$ & $=$ & 0,513 & ton.m & $\mathrm{L}=4,05 \mathrm{~m}$ \\
\hline $\mathrm{M}_{\mathrm{u}}$ & $=1.2 \mathrm{M}_{\mathrm{DL}}+1.6 \mathrm{M}_{\mathrm{LL}}$ & $=$ & 3,182 & ton.m & \\
\hline $\mathrm{M}_{\mathrm{s}}$ & $=M_{D L}+M_{L L}$ & $=$ & 2,481 & ton.m & \\
\hline
\end{tabular}

Gaya dalam struktur pada pelat lantai dirangkum pada tabel berikut. 
Tabel 2 Gaya dalam maksimum plat lantai

\begin{tabular}{llll}
\hline Loading & $\mathrm{M}^{+}$(ton.m) & $\mathrm{M}^{-}$(ton.m) & $\mathrm{V}$ (ton) \\
\hline Service Load & 21,46 & 28,42 & 27,96 \\
Ultimate Load & 32,19 & 42,63 & 41,94 \\
\hline
\end{tabular}

(Sumber : Software SAP2000, 2020)

(Keterangan : ultimate load $=1.5 \mathrm{x}$ service load)

\subsection{Perencanaan Balok Melintang dan Balok Area Mekanikal}

Berat mati yang merupakan berat sendiri elemen balok, dan berat sendiri pelat precast

Beban hidup merata sebesar $3,5 \mathrm{ton} / \mathrm{m}^{2}$

Beban truck 30 ton capacity.

Counter weight 21,24 T, dan Conveyor $20 \mathrm{~T}$.

Pada Stage 1, elemen precast beam berperilaku sebagai balok dengan dua tumpuan sederhana (simply supported beam).

Stage 1

$$
\begin{aligned}
& \text { qDL }=(0.8 \cdot 0.7) \mathrm{m}^{2} \cdot 2.4 \mathrm{t} / \mathrm{m}=1,344 \text { ton } / \mathrm{m} \\
& \text { qfloor }=(0.4 \cdot 5) \mathrm{m}^{2} \cdot 2.4 \mathrm{t} / \mathrm{m}^{3} \quad=4,800 \mathrm{ton} / \mathrm{m} \quad+ \\
& 6,144 \text { ton/ } \mathrm{m} \\
& \text { qLL }=0.25 \text { ton } / \mathrm{m} \cdot 5 \mathrm{~m} \quad=1,250 \text { ton } / \mathrm{m}
\end{aligned}
$$

\begin{tabular}{|c|c|c|c|c|}
\hline MDL & $=(1 / 8) \cdot \mathrm{qDL} \cdot \mathrm{L}^{2}$ & $=$ & 10,51 & ton.m \\
\hline VDL & $=(1 / 2) \cdot \mathrm{qDL} \cdot \mathrm{L}^{2}$ & $=$ & 11,37 & ton \\
\hline VDL & $=(1 / 2) \cdot \mathrm{qDL} \cdot \mathrm{L}$ & $=$ & 11,37 & ton \\
\hline MLL & $=(1 / 8) \cdot \mathrm{qLL} \cdot \mathrm{L}^{2}$ & $=$ & 2,14 & ton.m \\
\hline VLL & $=(1 / 2) \cdot \mathrm{qLL} \cdot \mathrm{L}$ & $=$ & 2,31 & ton \\
\hline
\end{tabular}

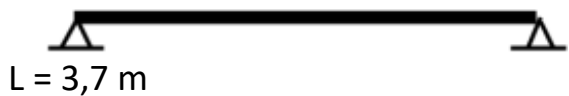

Member Force Stage 1

Service Load

$$
\begin{array}{lll}
\mathrm{Ms}=\mathrm{MDL}+\mathrm{MLL} & =12,65 & \text { ton.m } \\
\mathrm{Vs}=\mathrm{VDL}+\mathrm{VLL} & =13,68 & \text { ton }
\end{array}
$$

Ultimate

$$
\begin{array}{lll}
\mathrm{Mu}=1.2 \mathrm{MDL}+1.6 \mathrm{MLL} & =16,04 & \text { ton.m } \\
\mathrm{Vu}=1.2 \mathrm{VDL}+1.6 \mathrm{VLL} & =17,34 & \text { ton }
\end{array}
$$

Gaya dalam struktur pada balok melintang dirangkum pada tabel berikut.

Tabel 3 Gaya dalam maksimum balok melintang

\begin{tabular}{cccc}
\hline Loading & $\mathrm{M}^{+}$ & $\mathrm{M}^{-}$ & $\mathrm{V}$ (ton) \\
\hline Service Load & 40,36 & 53,28 & 48,63 \\
Ultimate & 60,54 & 79,92 & 72,95 \\
\hline
\end{tabular}

(Sumber : Software SAP2000, 2020) 
Gaya dalam struktur pada balok area mekanikal dirangkum pada tabel berikut.

Tabel 4 Gaya dalam maksimum balok area mekanikal

\begin{tabular}{cccc}
\hline Loading & $\mathrm{M}^{+}$ & $\mathrm{M}^{-}$ & $\mathrm{V}$ (ton) \\
\hline Service Load & 54,24 & 81,63 & 76,78 \\
Ultimate & 81,36 & 122,45 & 115,17 \\
\hline
\end{tabular}

(Sumber : Software SAP2000, 2020)

(Keterangan: ultimate load $=1.5 \mathrm{x}$ service load)

\subsection{Perencanaan Balok Memanjang}

- Beban hidup merata sebesar 3,5 ton $/ \mathrm{m}^{2}$

- Berat mati yang merupakan berat sendiri elemen balok, dan berat sendiri pelat precast

- Beban truck 30 ton capacity.

Pada Stage 1, elemen precast beam berperilaku sebagai balok dengan dua tumpuan sederhana (simply supported beam).

\section{Stage 1}

$$
\begin{array}{ll}
\text { qDL } & =(0.8 \cdot 0.7) \mathrm{m}^{2} \cdot 2.4 \mathrm{t} / \mathrm{m} \\
\text { qfloor } & =(0.4 \cdot 5) \mathrm{m}^{2} \cdot 2.4 \mathrm{t} / \mathrm{m}^{3} \\
\text { qLL } & =0.25 \mathrm{ton} / \mathrm{m} \cdot 5 \mathrm{~m}
\end{array}
$$$$
=1,344 \text { ton } / \mathrm{m}
$$$$
=\frac{4,800 \text { ton } / \mathrm{m}+}{6,144 \text { ton } / \mathrm{m}}
$$$$
=1,250 \text { ton } / \mathrm{m}
$$

\begin{tabular}{|c|c|c|}
\hline MDL & $=(1 / 8) \cdot \mathrm{qDL} \cdot \mathrm{L}^{2}$ & 9,408 \\
\hline VDL & $=(1 / 2) \cdot \mathrm{qDL} \cdot \mathrm{L}$ & 10,75 \\
\hline MLL & $=(1 / 8) \cdot \mathrm{qLL} \cdot \mathrm{L}^{2}$ & 1,914 \\
\hline VLL & $=(1 / 2) \cdot \mathrm{qLL} \cdot \mathrm{L}$ & 2,188 \\
\hline
\end{tabular}

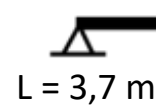

Member Force Stage 1

Service Load

$\begin{array}{llll}\mathrm{Ms}=\mathrm{MDL}+\mathrm{MLL} & =11,32 & \text { ton. } \mathrm{m} \\ \mathrm{Vs}=\mathrm{VDL}+\mathrm{VLL} & =12,94 & \text { ton }\end{array}$

Ultimate

$$
\begin{array}{lll}
\mathrm{Mu}=1.2 \mathrm{MDL}+1.6 \mathrm{MLL} & =14,35 & \text { ton.m } \\
\mathrm{Vu}=1.2 \mathrm{VDL}+1.6 \mathrm{VLL} & =16,40 & \text { ton }
\end{array}
$$

Gaya dalam struktur pada balok memanjang dirangkum pada tabel berikut.

Tabel 5 Gaya dalam maksimum balok memanjang

\begin{tabular}{cccc}
\hline Loading & $\mathrm{M}^{+}$ & $\mathrm{M}^{-}$ & $\mathrm{V}$ (ton) \\
\hline Service Load & 38,74 & 52,5 & 50,95 \\
Ultimate & 58,11 & 78,75 & 76,43 \\
\hline \multicolumn{4}{c}{ (Sumber : Software SAP2000, 2020) }
\end{tabular}

(Keterangan: ultimate load $=1.5 \mathrm{x}$ service load) 


\subsection{Perencanaan Penulangan Pilecap / Slab Fix Crane}

Untuk : $\mathrm{Fc}^{\prime} \leq 30 \mathrm{MPa}$,

Untuk: $\mathrm{Fc}^{\prime}>30 \mathrm{MPa}$,

$$
\begin{aligned}
\beta 1= & - \\
\beta 1=0.85-0.05 *\left(\mathrm{Fc}^{\prime}-30\right) / 7= & 0,814285714
\end{aligned}
$$

Faktor bentuk distribusi tegangan beton, $\quad \rightarrow \quad \beta 1=0,814285714$

Rasio tulangan pada kondisi balance,

$$
\rho_{\mathrm{b}}=\beta 1 * 0.85 * \mathrm{f}_{c}{ }^{\prime} / \mathrm{f}_{y} * 600 /\left(600+\mathrm{f}_{y}\right)=0,0363
$$

Faktor tahanan momen maksimum,

$$
\mathrm{R}_{\max }=0.75 * \rho_{\mathrm{b}} * \mathrm{f}_{y} *\left[1-1 / 2 * 0.75 * \rho_{\mathrm{b}} * \mathrm{f}_{y} /\left(0.85 * \mathrm{f}_{c}{ }^{\prime}\right)\right]=8,9040
$$

Faktor reduksi kekuatan lentur,

Jarak tulangan terhadap sisi luar beton,

Tebal efektif plat lantai,

Ditinjau plat lantai sebesar $1 \mathrm{~m}$,

Momen nominal rencana,

Faktor tahanan momen,

$$
\begin{aligned}
\varnothing= & 0,80 \\
\mathrm{~d}_{\mathrm{s}}=\mathrm{t}_{\mathrm{s}}+\emptyset / 2= & 87,5 \\
\mathrm{~d}=\mathrm{h}-\mathrm{d}_{\mathrm{s}}= & 1112,5 \\
\rightarrow \mathrm{b}= & 1000 \\
\mathrm{M}_{\mathrm{n}}=\mathrm{M}_{\mathrm{u}} / \varnothing= & 1009,043 \\
\mathrm{M}_{\mathrm{n}}=\mathrm{M}_{\mathrm{n}} * 10^{-6} /\left(\mathrm{b} * \mathrm{~d}^{2}\right)= & 0,81529 \\
\mathrm{R}_{\mathrm{n}}<\mathrm{R}_{\max } & \rightarrow(\mathbf{O K})
\end{aligned}
$$

$\mathrm{mm}$

$\mathrm{mm}$

$\mathrm{mm}$

$\mathrm{kNm}$

Rasio tulangan yang diperlukan :

$$
\rho=0.85 * \mathrm{f}_{c}^{\prime} / \mathrm{f}_{y} *\left[1-\sqrt{\left[1-2 * \mathrm{R}_{n} /\left(0.85 * \mathrm{f}_{c}^{\prime}\right)\right.}\right]=0,0021
$$

Rasio tulangan minimum,

Rasio tulangan yang terpakai,

Luas tulangan yang diperlukan,

Jarak tulangan yang diperlukan,

Jarak tulangan maksimum,

Jarak tulangan maksimum,

Jarak sengkang yang harus terpakai,

Diambil jarak sengkang,

Digunakan tulangan,

Luas tulangan terpakai,

$$
\begin{array}{rlr}
\mathrm{M}_{\text {min }} & =0,0022 & \\
\rightarrow \quad \rho= & 0,0022 & \\
\mathrm{~A}_{\mathrm{s}}=\rho * \mathrm{~b} * \mathrm{~d}= & 2781 & \mathrm{~mm} \\
\mathrm{~s}=\pi / 4 * \emptyset^{2} * \mathrm{~b} / \mathrm{A}_{\mathrm{s}} & =176 & \mathrm{~mm} \\
\mathrm{~s}_{\max }=2 * \mathrm{~h}= & 2400 & \mathrm{~mm} \\
\mathrm{~s}_{\max } & =200 & \mathrm{~mm} \\
\mathrm{~s} & =176 & \mathrm{~mm} \\
\mathrm{~s} & =125 & \mathrm{~mm} \\
\varnothing \mathbf{2 2}- & \mathbf{1 2 5} & \\
\mathrm{A}_{\mathrm{s}}=\pi / 4 * \emptyset^{2} * \mathrm{~b} / \mathrm{s} & =3927 & \mathrm{~mm}
\end{array}
$$

\section{KESIMPULAN}

Berdasarkan perhitungan Analisa Perencanaan Struktur Dermaga Emergency Jetty Trucking Kapasitas 10.000 dwt Pelabuhan Ratu Sukabumi Jawa Barat menghasilkan beberapa kesimpulan sebagai berikut : Struktur dermaga ini terdiri dari Struktur atas (Plat lantai,balok dan fender) dan Struktur bawah (poer dan pondasi tiang pancang), kombinasi beban yang bekerja didalamnya, antara lain : Beban Mati, Beban Hidup Terdistribusi Merata sebesar 3,5 ton $/ \mathrm{m}^{2}$, Beban Truck berat maksimumnya 300 kN, Beban Fix Grab Crane kapasitas $30 \mathrm{~T}$ sejumlah 2 unit, Beban Conveying, Beban Sandar Kapal dengan kecepatan berthing sebesar $0.25 \mathrm{~m} / \mathrm{s}$ saat kondisi abnormal adalah 28,3 ton-m (283 kN), Beban Mooring / Tambat, Beban Arus dengan kecepatan arus kala ulang 10 tahun adalah sebesar 1,06 m/s, Beban Gelombang dengan Tinggi gelombang 3,5 m dan Periode 5,4 detik (kala ulang 10 tahun, BPPU ITS 2017), Beban Angin Kecepatan angin untuk kala ulang 10 taahun adalah $20,6 \mathrm{~m} / \mathrm{s}$, Beban Temperatur direncanakan dengan rentang $33^{\circ} \mathrm{C}$, Beban Gempa dan Kombinasi Pembebanan. Dermaga ini menampung 1 kapal tongkang untuk bongkar muat batu bara dengan dimensi semagai berikut : Panjang Dermaga 110,4 $\approx 120 \mathrm{~m}$, Lebar Dermaga $31 \mathrm{~m}$, Mobilitas batu bara 1250 ton/hour, Memiliki 2 jalur truck, Kapasitas Truck $20 \mathrm{~m}^{3}$, dan Elevasi deck dermaga $+3.8 \mathrm{~m}$ (ref 0.00 MSL). Fasilitas yang terdapat di dermaga ini antara lain : Fender jenis Trelleborg - SCK Cell 1150 E 1.5 dan Bollard jenis Tee bollard dengan kapasitas 50 ton. Dermaga ini menggunakan material beton bertulang dengan karakteristik mutu beton sebagai berikut : Floor/Slab, Beam, Pile cap \& Headstock, Concrete fill for pile yaitu K.430; f $\mathrm{c}=$ $35 \mathrm{MPa}$. Sedangkan Precast I Girder yaitu K.500 ; fc = 41,5 MPa. Dermaga ini memiliki struktur atas dan struktur bawah dengan hasil perencanaan sebagai berikut :

a. Tiang Pancang bertipe SPP $\varnothing 914 \mathrm{~mm}(\mathrm{t}=16 \mathrm{~mm} \& \mathrm{t}=22 \mathrm{~mm})$ dengan detail : Panjang Tiang Tertanam (PD) 20,45 m, Panjang Tiang Total (PL) 30,45 m $\approx 31 \mathrm{~m}$, Tulangan Utama 20 D25, Sengkang Spiral D13150 dan Mutu Baja (Fy) 315 Mpa.

b. Pelat Lantai/Slab dengan detail : Tebal Pelat $400 \mathrm{~mm}$, Mutu Beton (Fc) 35 Mpa, Mutu Baja (Fy) 400 Mpa, Tulangan Tumpuan D22-100, Tulangan Lapangan D22-200. 
c. Balok Melintang dan Memanjang dengan ukuran 700x800x200 mm, dan detailnya yaitu : Mutu Beton (Fc) 35 Mpa, Mutu Baja (Fy) 400 Mpa, Tulangan utama tumpuan dan lapangan 7 D25, Tulangan Sengkang tumpuan D16-100 dan lapangan D16-150.

d. Balok Area Mekanikal dengan ukuran 1200x800x400 mm, dan detailnya yaitu :

Mutu Beton ( $\mathrm{Fc}$ ) $35 \mathrm{Mpa}$, Mutu Baja (Fy) $400 \mathrm{Mpa}$, Tulangan tarik tumpuan 6+6D25 dan Lapangan 10+2D25, Tulangan tekan tumpuan 10+2D25 dan lapangan 6+6D25, Tulangan sengkang tumpuan 4 D16100 dan lapangan 4D16-150.

e. Pilecap 1500x1500x800mm dengan tulangan utama D25-150, Pilecap Slab Fix Crane 8000x8700x 1200mm dengan tulangan utama D22-125 dan Pilecap Hopper 25300x 14000x 1200mm dengan tulangan utama D22-125 serta mutu material dengan detail : Mutu Beton (Fc) 35 Mpa, Mutu Baja (Fy) 400 Mpa.

\section{SARAN}

Terdapatg beberapa saran yang bisa penulis sampaikan dari Perencanaan Struktur Dermaga Emergency Jetty Trucking Kapasitas 10.000 dwt Pelabuhan Ratu Sukabumi Jawa Barat ini antara lain, untuk penelitian berikutnya, peneliti dapat menganalisis biaya, waktu serta mengenai pelaksanaan konstruksi terhadap hasil perencanaan ini dan untuk menghindari terjadinya pendangkalan akibat lumpur dan lain sebagainya di sekitar dermaga perlu dilakukan pengerukan sekiranya kurang lebih minimal 5-10 tahun. Perencanaan selanjutnya, peneliti dapat melakukan perencanaan pelebaran desain layout dermaga dan fasilitas tambahan lainnya serta analisis perencanaan jalan akses menuju dermaga sehingga proses bongkar muat berjalan lancar kemudian juga dapat melakukan analisis penentuan titik pilling secara rinci pada penelitian berikutnya sehingga saat pelaksaan tidak melenceng dari titik yang ditentukan dan diharapkan dapat memvisualisasikan metode pelaksanaan dari dermaga yang dibuatnya serta dapat memberikan gambaran yang jelas kepada pembaca, terakhir peneliti dalam melakukan perencanaan selanjutnya perlu melakukan analisis uji konstruksi dan beban ketika selesai dibangun terhadap perencanaan dermaganya.

\section{DAFTAR PUSTAKA}

American Concrete Institute (ACI): ACI318-05, Building Code Requirements for Structural Concrete, 2005. American Institute of Steel Construction (AISC), 1989a, Manual of Steel Constructions - Allowable Stress Design, 9th ed. Chicago.

Badan Standar Nasional Indonesia (SNI), SNI 03-1726-2012, Standar Perencanaan Ketahanan Gempa untuk Struktur Bangunan Gedung, 2012.

Badan Standar Nasional Indonesia (SNI), SNI 03-1727-2002, Tata Cara Perhitungan Pembebanan untuk Bangunan Rumah dan Gedung, 2002.

Badan Standar Nasional Indonesia (SNI), SNI 03-2847-2002, Tata Cara Perhitungan Struktur Beton untuk Bangunan Gedung, 2002.

Badan Standar Nasional Indonesia (SNI), SNI T02-2005, Standar Pembebanan untuk Jembatan; UBC 1997, Uniform Building Code 1997.

British Standard Code of Practice for Marine Structures - Part 1-6. BS6349: British Standard Institution, 2013.

Muhammad Hanif Al-Basyar. 2016. Perencanaan Struktur Dermaga General Cargo Pelabuhan Awerange, Kab. Barru Sulawesi Selatan Kapasitas 15.000 DWT. Surabaya (ID): Institut Teknologi Sepuluh November.

Razif Faizal Sany. 2018. Perencanaan Struktur Dermaga Peti Kemas Di Kendari Marina, Sulawesi Tenggara. Bandung (ID): Institut Teknologi Bandung.

Standard Design Criteria For Port In Indonesia, 1984, Maritime Sector Development Programme, Directorate General Of Sea Communications.

Technical Standards for Port and Harbor Facilities In Japan - The Overseas Coastal Area Development Institute of Japan, 2009.

Triatmodjo, Bambang. 2009. Perencanaan Pelabuhan. Yogyakarta: Beta Offset.

Yoga Pratama. 2016. Perencanaan Dermaga Pelabuhan Marina Boom Kabupaten Banyuwangi. Jember (ID): Universitas Jember. 